\title{
STUDI PENGOTOR PADA PENDINGIN PRIMER REAKTOR RSG GAS SETELAH 30 TAHUN BEROPERASI
}

\section{STUDY OF PRIMARY COOLANT IMPURITIES IN REACTOR RSG GAS AFTER 30 YEARS OF OPERATION}

\author{
Elisabeth Ratnawati1), Diyah Erlina Lestari 1), Th. Rina Mulyaningsih 2) \\ 1) Pusat Reaktor Serba GunaGedung 30, Puspiptek, Serpong, Tangerang Selat/an, Banten 15310 \\ 2)Pusat Sains dan Teknologi Bahan Maju, Gedung 40, Puspiptek, Serpong, Tangerang Selatan, Banten 15310 \\ e-mail: .betty@batan.go.id.
}

Diterima 14 Oktober 2017, diterima dalam bentuk perbaikan 18 Januari 2018, disetujui 1 Maret 2018

\begin{abstract}
ABSTRAK
STUDI PENGOTOR PADA PENDINGIN PRIMER REAKTOR RSG GAS SETELAH 30 TAHUN BEROPERASI. Sistem pendingin primer reaktor dengan air sebagai media berfungsi sebagai pendingin, moderator dan perisai radiasi. Setelah beroperasi selama 30 tahun diduga terdapat pengotor yang mengendap pada dasar kolam, yang berasal dari produk korosi teraktivasi maupun akibat kegiatan pemanfaatan reaktor. Untuk mengurangi jumlah endapan pengotor dan mengetahui jenis nuklida yang terkandung di dalamnya maka dilakukan penyedotan air dasar kolam reaktor dengan pompa benam pada saat reaktor shut down di akhir teras 91. Air hasil penyedotan dicacah menggunakan Multi channel analyzer (MCA) Ortec A65-B32 Maestro32 dengan detektor $\mathrm{HPGe}$. Hasil pencacahan menunjukkan adanya nuklida ${ }^{51} \mathrm{Cr},{ }^{124} \mathrm{Sb},{ }^{125} \mathrm{Sb},{ }^{46} \mathrm{Sc},{ }^{59} \mathrm{Fe},{ }^{65} \mathrm{Zn}$ dan ${ }^{60} \mathrm{Co}$. Endapan yang terbentuk dianalisis dengan menggunakan metode AAN. Hasil analisis endapan menunjukkan adanya kesamaan dengan nuklida yang teridentifikasi dalam sampel air hasil penyedotan. Beberapa jenis unsur yang sama juga teridentifikasi dalam air bekas pencucian batu topaz pra iradiasi. Hasil pemantauan rutin terhadap kualitas air pendingin menunjukkan bahwa aktivitas nuklida yang teridentifikasi masih berada di bawah nilai yang tercantum dalam dokumen Laporan Analisis Keselamatan. Ini disebabkan karena sistem purifikasi yang berfungsi dengan baik. Namun demikian penyedotan secara berkala perlu dilakukan pengotor yang mengendap di dasar tangki kolam reaktor, di samping itu perlu diperhatikan pula proses pencucian batu topaz pra iradiasi sesuai dengan prosedur yang ditetapkan untuk memperkecil kemungkinan terbentuknya pengotor dalam sistem pendingin primer, mengingat bahwa iradiasi batu topaz pada posisi incore dilakukan dengan menggunakan wadah terbuka.
\end{abstract}

Kata kunci : Pendingin primer, reaktor, pengotor, produk korosi.

\section{ABSTRACT}

STUDY OF PRIMARY COOLANT IMPURITIES IN REACTOR RSG GAS AFTER 30 YEARS OF OPERATION. The primary cooling water reactor functions are as coolant, moderator and radiation shielding. After operating for 30 years it is suspected that there are impurities deposited in the bottom of the pond, which comes from activated corrosion products as well as due to the activities of the utilization of the reactor. To reduce the amount of impurities deposition and to know the type of nuclide contained therein, the water is suctioned from the bottom of the reactor pool with the submerged pump at the time the reactor shut down. The suctioned water is counted using a Multi channel analyzer (MCA) Ortec A65-B32 Maestro-32 with a HPG detector. The counting results showed the presence of nuclides ${ }^{51} \mathrm{Cr},{ }^{124} \mathrm{Sb},{ }^{125} \mathrm{Sb},{ }^{46} \mathrm{Sc},{ }^{59} \mathrm{Fe},{ }^{65} \mathrm{Zn}$ and ${ }^{60} \mathrm{Co}$. The sediment that formed was analyzed using AAN method. Sediment analysis results showed a similarity to identified nuclides in the sample water. Several type of the same elements also identified in water washing preirradiated topaz stone. Nevertheless, routine monitoring of the quality of cooling water shows value in the normalrange. This is because the performance of ion exchange resins is good. Periodic suctioning is necessary to reduce impurities deposited in the reactor pool tanks, besides that it is also necessary to consider the process of washing pre irradiated topazstones in accordance with established procedures to minimize the possibility of impurities formation, because the irradiation of topaz at incore position using open container.

Keywords : Primary coolant, reactor, impurities, corrosion product. 


\section{PENDAHULUAN}

S ebagian besar reaktor daya komersial dan reaktor riset di dunia, menggunakan air sebagai pendingin primer untuk mengambil panas dari reaksi fisi dan sebagai moderator. Air juga digunakan sebagai perisai radiasi melindungi personil yang bekerja di sekitarnya. Kualitas air pendingin harus diperhatikan karena akan berpengaruh terhadap korosi pada plat elemen bakar maupun sistem reaktor. Berbagai macam bahan logam umumnya digunakan dalam sistem reaktor nuklir, seperti stainless steels digunakan untuk komponen dalam sistem pendingin primer, zirconium alloy digunakan untuk cladding elemen bakar dan aluminium digunakan untuk tangki reaktor. Kualitas air terutama pH dan konduktivitas sangat berpengaruh terhadap terbentuknya korosi pada bahanbahan ini di sistem reaktor [1].

Reaktor Serba Guna G.A. Siwabessy (RSG-GAS) merupakan reaktor riset jenis kolam terbuka yang memiliki daya maksimum $30 \mathrm{MW}$. Menggunakan elemen bakar campuran $\mathrm{U}_{3} \mathrm{O}_{8}-\mathrm{Al}_{/} \mathrm{U}_{3} \mathrm{Si}_{2}-\mathrm{Al}$ dengan pengkayaan ${ }^{235 \mathrm{U}}$ sebesar $19,75 \%$. Reaktor menggunakan air ringan sebagai pendingin teras, moderator dan perisai radiasi. Pemanfaatan operasi reaktor yang dilakukan saat ini diantaranya adalah untuk produksi isotop, iradiasi sampel penelitian, pengujian EBU (elemen bakar uji), dan pemuliaan batu topaz [2]. Pemuliaan batu topaz di dalam reaktor dilakukan dengan mengiradiasi topaz baik untuk posisi incore maupun outcore. Untuk posisi incore, topaz diletakkan dalam suatu wadah terbuka sehingga bersinggungan langsung dengan air pendingin primer.

Selama pengoperasian reaktor maka dihasilkan juga berbagai nuklida radioaktif yang kemungkinan mempengaruhi kualitas pendingin primer. Neutron dari hasil reaksi fisi dalam reaktor, menyebabkan terjadinya reaksi aktivasi dalam pendingin primer yang dapat menghasilkan unsur-unsur radioaktif. Selain itu debu halus dari udara sekitar experimental hall dapat sampai ke permukaan kolam dan dapat mengendap di dasar kolam tergantung pada berat jenisnya.

Sumber aktivasi yang terjadi dalam pendingin primer meliputi: aktivasi air kolam, aktivasi garam residu terkandung dalam air kolam, aktivasi kontaminan uranium pada pelat bahan bakar karena faktor fabrikasi dan aktivasi hasil korosi dari bahan struktur di dalam sistem pendingin primer.

Kualitas air pendingin ini secara reguler dimonitor hingga sesuai dengan spesifikasi yang dipersyaratkan. Pada sistem pendingin primer, air secara kontinyu dilewatkan ke sistem purifikasi yang terdiri dari filter mekanik dan resin penukar ion [2]. Penelitian Elisabeth dkk (2012), menunjukkan bahwa adanya kegiatan iradiasi batu topaz tidak mempengaruhi kualitas air pendingin reaktor karena kinerja resin penukar ion dan filter mekanik yang terjaga baik [3].

Setelah dioperasikan selama kurang lebih 30 tahun maka dimungkinkan bahwa pengoperasian reaktor dan aplikasinya dapat menimbulkan adanya endapan di dasar kolam reaktor yang diduga akan mempengaruhi kualitas air pendingin reaktor dan dapat meningkatkan paparan radiasi di sekitar kolam reaktor. Berdasarkan dugaan tersebut maka timbul gagasan untuk melakukan penyedotan terhadap air dan pengotor dari dasar kolam reaktor dengan menggunakan pompa benam. Hasil sedotan pompa benam ditampung untuk dianalisis dengan spektrometer gamma, sehingga dapat diketahui jenis nuklida yang terdapat di dalamnya. Di samping itu juga dilakukan pengendapan dan penyaringan kotoran dari air hasil sedotan pompa benam untuk dilakukan analisis secara kualitatif maupun kuantitatif. Analisis dilakukan dengan metode analisis aktivasi neutron (AAN).

Penelitian ini bertujuan untuk mengetahui kondisi air pendingin reaktor yang diambil dari dasar kolam reaktor beserta jenis pengotor yang ada di dalamnya setelah reaktor beroperasi selama 30 tahun sekaligus melakukan pengecekan kembali pengaruh iradiasi batu topaz terhadap kualitas air pendingin reaktor. Diharapkan dari hasil yang akan diperoleh dapat digunakan sebagai bahan pertimbangan dalam pengambilan keputusan yang berkaitan dengan utilisasi RSG GAS.

\section{METODOLOGI}

\section{Sampling dan Preparasi Sampel}

Air pendingin primer diambil dari dasar kolam dengan menggunakan pompa benam. Pengambilan sampel air dilakukan pada saat reaktor tidak beroperasi diakhir teras 91, pada duapuluh lima (25) hari setelah reaktor shut down. Sampel air dimasukkan ke dalam merineli 1 liter, dan dilakukan pencacahan langsung dengan menggunakan 
peralatan spektrometri gamma jenis HpGe GC0918 dengan resolusi 1,8 keV dan efisiensi relatif 9\% pada energi $1332 \mathrm{keV}$.

Pengambilan padatan dilakukan dengan mengendapkan sampel selama 14 hari, kemudian dilakukan penyaringan dan pengeringan. Secara visual dapat diketahui endapan berwarna abu-abu kecoklatan beserta beberapa serpihan kecil yang berkilau. Untuk mengidentifikasi unsur yang terkandung dalam sampel endapan tersebut dilakukan dengan teknik analisis aktivasi neutron. Sampel endapan ditimbang dengan berat $\pm 25 \mathrm{mg}$ dan dimasukkan ke dalam vial LDPE (Low Density Poly Ethilene) kemudian dimasukkan dalam kapsul aluminium untuk diiradiasi dalam fasilitas sistem Rabbit RSG GAS. Sebagai pembanding digunakan bahan acuan standar (SRM) 2702 Inorganic in Marine Sediment dan SRM 2780 Hard Rock Mine Waste.Sampel dan standar diiradiasi selama 1jam, kemudian didinginkan selama 7 hari. Sampel paska iradiasi dicacah menggunakan spektrometri gamma dengan tipe yang sama seperti alat pencacahan air pendingin primer. Untuk kontrol mutu metode digunakan NIST SRM 2704 Bufallo river sediment.

\section{Analisis Kualitatif dan Kuantitatif}

Analisis kualitatif terhadap spektrum gamma hasil pencacahan sampel, dilakukan dengan menggunakan bantuan perangkat lunak Genie 2000. Dari sini dapat diketahui jenis radionuklida terkandung di dalam sampel air, dan dengan metode perbandingan dapat dihitung aktivitas radionuklida yang terkandung dalam air pendingin primer. Sedangkan konsentrasi unsur dalam endapan dasar kolam dan endapan air cucian batu topaz ditentukan dengan metode AAN-komparatif.

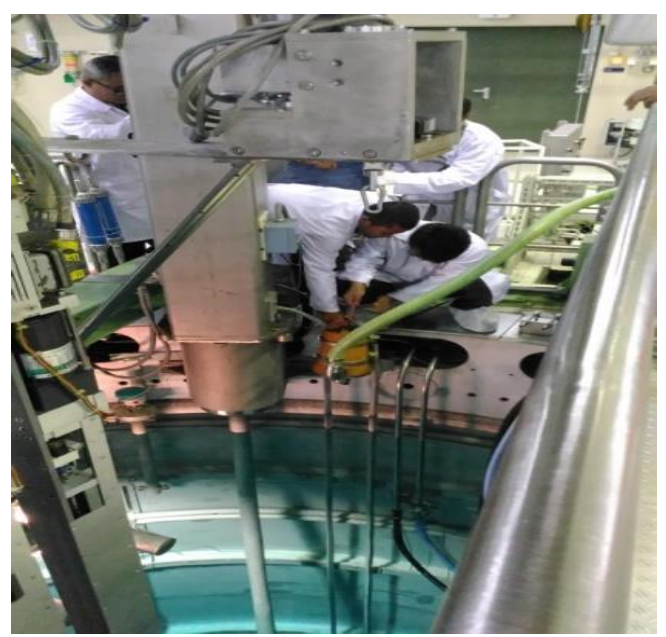

Gambar 1. Pemasangan pompa benam.

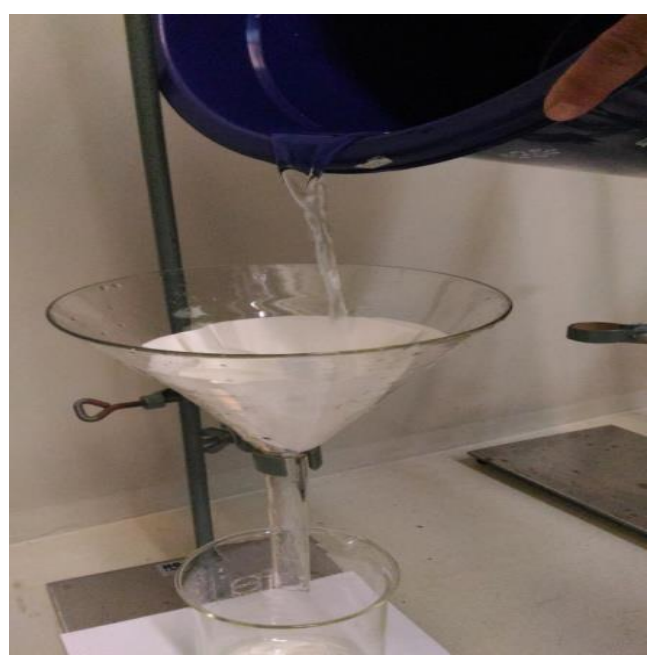

Gambar 3. Proses penyaringan.

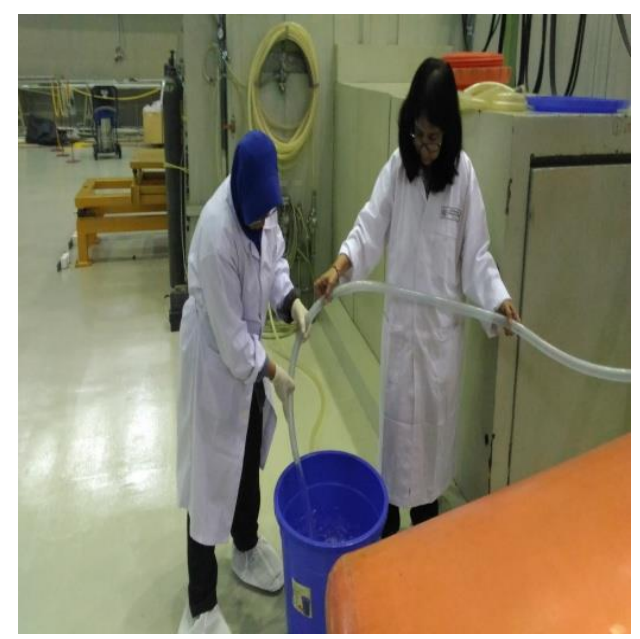

Gambar 2. Pengambilan air dan endapan.

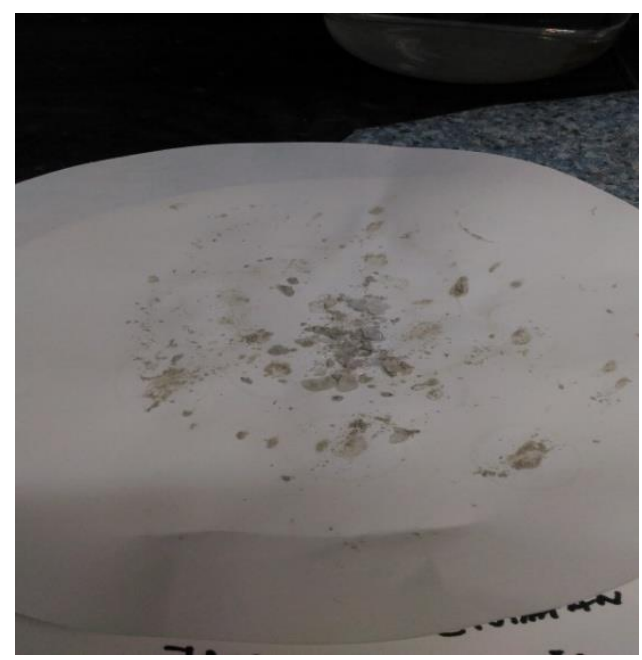

Gambar 4. Endapan. 


\section{HASIL DAN PEMBAHASAN}

Penyedotan air dari dasar kolam reaktor dilakukan setelah reaktor beroperasi dalam kurun waktu yang relatif lama. Berbagai kegiatan yang dilakukan sehubungan dengan utilisasi reaktor dimungkinkan turut menyumbang pengotor dalam air pendingin reaktor. Untuk mengetahui jenis radionuklida pemancar gamma yang terkandung di dalam air serta endapannya, maka air sedotan ditampung untuk dianalisis dan endapan yang diperoleh dianalisis pula secara kualitatif dan kuantitatif. Tabel.1 menunjukkan hasil identifikasi dan pengukuran aktivitas radionuklida terhadap air hasil sedotan pompa benam.

Tabel 1. Aktivitas Unsur Radionuklida dalam Air Pendingin Primer (Bq/liter) yang diambil dari sedotan pompa benam.

\begin{tabular}{ccccccc}
\hline $\begin{array}{c}\text { Radio- } \\
\text { nuklida }\end{array}$ & $\begin{array}{c}\text { Energi } \\
(\mathrm{keV})\end{array}$ & $\begin{array}{c}\text { Waktu } \\
\text { Paro }\end{array}$ & $\begin{array}{c}\text { Aktivitas } \\
\text { Sampel - } 1\end{array}$ & $\begin{array}{c}\text { Aktivitas } \\
\text { Sampel-2 }\end{array}$ & Rerata & LAK [2] \\
\hline${ }^{51} \mathrm{Cr}$ & 320,08 & 27,7 hari & $9,931 \times 10^{2}$ & $2,978 \times 10^{3}$ & $1,986 \times 10^{3}$ & $3,700 \times 10^{4}$ \\
${ }^{124} \mathrm{Sb}$ & 1690,98 & 60,2 hari & $7,306 \times 10^{2}$ & $5,731 \times 10^{2}$ & $6,618 \times 10^{2}$ & \\
${ }^{125} \mathrm{Sb}$ & 427,89 & 2,73 tahun & $2,913 \times 10^{2}$ & $2,473 \times 10^{2}$ & $2,693 \times 10^{2}$ & $8,991 \times 10^{-2}$ \\
${ }^{46} \mathrm{Sc}$ & 889,28 & 83,81 hari & $3,602 \times 10^{2}$ & $1,300 \times 10^{2}$ & $2,451 \times 10^{2}$ & \\
${ }^{59} \mathrm{Fe}$ & 1099,25 & 44,5 hari & $1,659 \times 10^{2}$ & $3,689 \times 10^{2}$ & $2,674 \times 10^{2}$ & $2,331 \times 10^{2}$ \\
${ }^{65} \mathrm{Zn}$ & 1115,55 & 243,9 hari & $3,384 \times 10^{3}$ & $1,918 \times 10^{3}$ & $2,651 \times 10^{3}$ & \\
${ }^{60} \mathrm{Co}$ & 1173,24 & 5,27 tahun & $7,576 \times 10^{4}$ & $5,244 \times 10^{4}$ & $6,410 \times 10^{4}$ & $2,109 \times 10^{2}$ \\
\hline
\end{tabular}

Dari Tabel 1 ini dapat diketahui radionuklida yang teridentifikasi dalam air meliputi 7 unsur. Radionuklida terdeteksi merupakan radionuklida dengan waktu paro panjang. Hal ini disebabkan karena pencacahan sampel air dilakukan setelah reaktor shut down selama 25 hari sehingga radionuklida dengan waktu paro pendek dan medium sudah meluruh habis. Unsur ${ }^{51} \mathrm{Cr}$ terbentuk dari aktivasi ${ }^{50} \mathrm{Cr}(\mathrm{n}, \mathrm{\gamma})$, ${ }^{59} \mathrm{Fe}$ dari aktivasi ${ }^{58} \mathrm{Fe}(\mathrm{n}, \mathrm{\gamma})$, dan ${ }^{60} \mathrm{Co}$ dari aktivasi ${ }^{59} \mathrm{Co}(\mathrm{n}, \mathrm{y})$. Unsur-unsur ini kemungkinan merupakan produk korosi dari bahan struktur yang teraktivasi di dalam pendingin primer [1] atau tepatnya dari pipa pendingin primer yang terbuat dari stainless steel (SS)316 [4]. Unsur ${ }^{65 Z n}$ terbentuk dari aktivasi ${ }^{64} \mathrm{Zn}(\mathrm{n}, \mathrm{\gamma}),{ }^{125} \mathrm{Sb}$ terbentuk dari ${ }^{124} \mathrm{Sn}(\mathrm{n}, \mathrm{\gamma})$, dan ${ }^{123} \mathrm{Sb}(2 \mathrm{n}, \mathrm{\gamma})$, sedangkan ${ }^{124} \mathrm{Sb}$ dari ${ }^{123} \mathrm{Sb}(\mathrm{n}, \mathrm{y})$. Radionuklida ini kemungkinan terbentuk dari aktivasi kontaminan uranium pada plat elemen bakar karena faktor fabrikasi [2]. Apabila dilihat aktivitas rerata (bq/liter) untuk radionuklida ${ }^{51} \mathrm{Cr}$ di dalam air pendingin primer masih di bawah nilai yang tertera dalam Laporan Analisis Keselamatan (LAK) RSG-GAS. Tetapi untuk radionuklida ${ }^{125} \mathrm{Sb},{ }^{59} \mathrm{Fe}$ dan ${ }^{60} \mathrm{Co}$ ada di atas nilai perhitungan dengan perangkat lunak OREGON-2 yang tercantum dalam dokumen LAK [2]. Unsur ${ }^{60} \mathrm{Co}$ bersama sama dengan ${ }^{58} \mathrm{Co},{ }^{51} \mathrm{Cr},{ }^{54} \mathrm{Mn}$ dan ${ }^{59} \mathrm{Fe}$ merupakan radionuklida produk korosi yang paling penting dalam air pendingin reaktor [5].

Konsentrasi unsur radionuklida dalam pendingin primer tergantung lamanya operasi reaktor, makin lama reaktor beroperasi makin besar radionuklida yang terbentuk. Selama reaktor beroperasi normal ${ }^{56} \mathrm{Mn}$ mendominasi corrosion product activity. Radionuklida ${ }^{56} \mathrm{Mn}$ aktivitas saturasi akan dicapai pada kira-kira 150 jam setelah reaktor start up, dan setelah reaktor shutdown akan didominasi oleh ${ }^{58} \mathrm{Co}$ dan ${ }^{60} \mathrm{Co}$ [6]. Produk korosi teraktivasi mempunyai trend mengalami penurunan apabila pH air mengalami kenaikan $[7,8]$.

Analisis unsur dalam sampel endapan dan air cucian batu topas digunakan metode AAN. Untuk meyakinkan bahwa metode yang digunakan valid, maka digunakan NIST SRM 2704 Bufallo river sediment sebagai kontrol mutu internal pada penelitian ini. Hasil kontrol mutu internal metode disajikan pada Gambar 5. Hasil pengukuran $\mathrm{Fe}, \mathrm{Co}, \mathrm{La}, \mathrm{Sb}, \mathrm{Cr}$, Sc dan $\mathrm{Zn}$ yang diperoleh apabila dibandingkan nilai sertifikat mendekati $\cong 1$, hampir semua terletak pada satu garis dan memiliki nilai $Z$ score di dalam range \pm 3 . Hal ini berarti bahwa data hasil pengujian dengan AAN valid. 


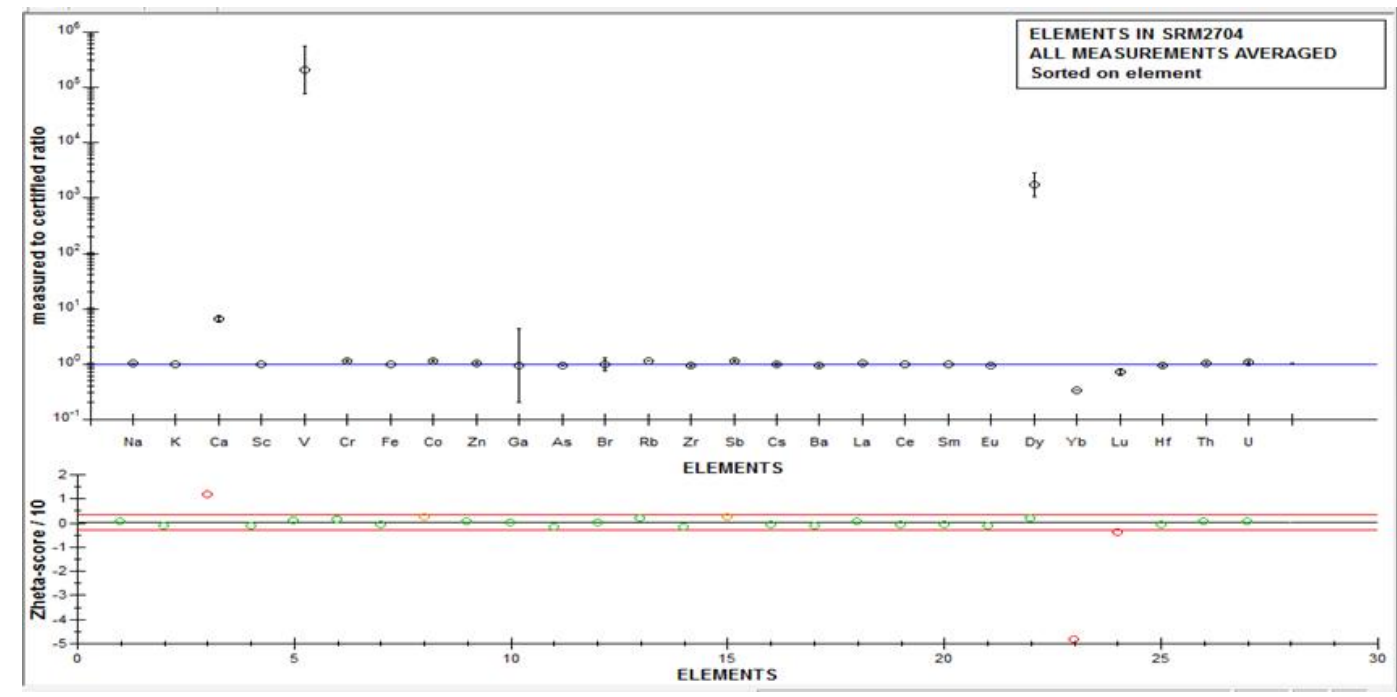

Gambar 5. Hasil kontrol mutu metode menggunakan NIST SRM 2704 Bufallo river sediment.

Analisis dengan metode AAN terhadap endapan yang terdapat pada air dasar kolam reaktor menunjukkan radionuklida yang terkandung dalam endapan tersebut dan konsentrasinya seperti tercantum pada Tabel 2.

Tabel 2. Konsentrasi Unsur dalam Sampel endapan diambil dari kolam reaktor.

\begin{tabular}{ccc}
\hline Unsur & Konsentrasi $(\mu \mathrm{g} / \mathrm{g})$ & $\begin{array}{l}\text { Ketidakpastian } \\
\text { pengukuran }(\mu \mathrm{g} / \mathrm{g})\end{array}$ \\
\hline${ }^{51} \mathrm{Cr}$ & $3,002 \times 10^{4}$ & $8,758 \times 10^{3}$ \\
${ }^{65} \mathrm{Zn}$ & $1,520 \times 10^{3}$ & $4,768 \times 10^{1}$ \\
${ }^{59} \mathrm{Fe}$ & $8,774 \times 10^{4}$ & $3,337 \times 10^{3}$ \\
${ }^{60} \mathrm{Co}$ & $8,756 \times 10^{1}$ & $1,239 \times 10^{1}$ \\
${ }^{140} \mathrm{La}$ & $8,104 \times 10^{2}$ & 4,470 \\
${ }^{46} \mathrm{Sc}$ & 1,502 & $8,367 \times 10^{-02}$ \\
${ }^{124} \mathrm{Sb}$ & $5.294 \times 10^{1}$ & 4.872 \\
${ }^{125} \mathrm{Sb}$ & $3.643 \times 10^{1}$ & 1.756 \\
& & \\
\hline
\end{tabular}

Hasil pengukuran pada Tabel 2 menunjukkan adanya 8 unsur yang terdeteksi dalam endapan. Unsurunsur tersebut memiliki kemiripan dengan unsur yang teridentifikasi dalam sampel air pendingin yang diambil dengan sedotan pompa benam (Tabel 1). Dalam sampel air pendingin, ${ }^{140} \mathrm{La}$ (Lanthanum) tidak dapat terdeteksi, tetapi dalam endapan yang terbentuk dapat terdeteksi. Hal ini kemungkinan karena unsur tersebut memiliki konsentrasi yang relatif kecil dalam larutan, sehingga tidak terdeteksi Apabila dibandingkan dengan hasil analisis terhadap air bekas pencucian batu topaz sebelum diiradiasi, maka ada kemiripan unsur-unsur yang terkandung dalam endapan tersebut dengan unsur hasil pencucian batu topaz yang nampak pada Tabel 3 berikut ini.

Tabel 3. Konsentrasi Unsur pengotor pada endapan air cucian batu topaz.

\begin{tabular}{ccc}
\hline Unsur & Konsentrasi $(\mu \mathrm{g} / \mathrm{g})$ & $\begin{array}{l}\text { Ketidakpastian } \\
\text { pengukuran }(\mu \mathrm{g} / \mathrm{g})\end{array}$ \\
\hline${ }^{60} \mathrm{Co}$ & $8,46 \times 10^{-1}$ & $1,9 \times 10^{-1}$ \\
${ }^{59} \mathrm{Fe}$ & $1,11 \times 10^{+2}$ & 8,93 \\
${ }^{51} \mathrm{Cr}$ & $2,046 \times 10^{1}$ & 1,37 \\
${ }^{65} \mathrm{Zn}$ & $1,268 \times 10^{1}$ & 0,6 \\
\hline
\end{tabular}


Berdasarkan hasil analisis dengan metode AAN terhadap endapan air cucian batu topaz sebelum diiradiasi menunjukkan bahwa sampel tersebut mengandung unsur-unsur pengotor $\mathrm{Co}, \mathrm{Fe}, \mathrm{Cr}$ dan $\mathrm{Zn}$ (Tabel 3). Apabila diperhatikan, unsur-unsur tersebut juga terdeteksi dalam endapan yang terdapat pada air hasil sedotan pompa dasar kolam, tetapi dengan konsentrasi yang lebih rendah. Hal ini dapat terjadi karena endapan dari air sedotan pompa benam merupakan akumulasi dari pengotor dalam waktu yang relatif lama. Meskipun air dan endapan dari dasar kolam reaktor menunjukkan hasil demikian, namun berdasarkan hasil pengukuran rutin terhadap air pendingin primer sebelum dan sesudah melewati resin penukar ion sistem purifikasi pada saat yang sama masih berada di bawah batas yang ditetapkan (Tabel 4). Sistem purifikasi yang berfungsi dengan baik menyebabkan kualitas air tetap terjaga. Hasil pengukuran aktivitas nuklida dalam air pendingin primer pada saat yang hampir sama menunjukkan bahwa aktivitas semua nuklida teridentifikasi mengalami penurunan setelah melalui resin penukar ion dalam sistem purifikasi, dan memiliki nilai di bawah nilai yang ditampilkan dalam Tabel VI.12 Laporan Analisis keselamatan [2]

Tabel 4. Hasil Pengukuran Air Primer Sistem Purifikasi (KBE01).

\begin{tabular}{ccccc}
\hline UNSUR & $\begin{array}{c}\text { ENERGI } \\
(\mathrm{keV})\end{array}$ & $\begin{array}{c}\text { Aktivitas }^{*} \\
\text { KBE01- IN }(\mathrm{bq} / \mathrm{l})\end{array}$ & $\begin{array}{c}\text { Aktivitas } \\
\text { KBE01-OUT }(\mathrm{bq} / \mathrm{l})\end{array}$ & $\begin{array}{c}\text { Aktivitas } \\
\text { LAK }(\mathrm{bq} / \mathrm{l})\end{array}$ \\
\hline${ }^{99 \mathrm{Mo}}$ & 140,51 & $2,857 \times 10^{1}$ & 1,209 & - \\
${ }^{51} \mathrm{Cr}$ & 320,08 & $4,543 \times 10^{1}$ & 0,000 & $3,700 \times 10^{4}$ \\
${ }^{132} \mathrm{Te}$ & 228 & $1,211 \times 10^{2}$ & $1,061 \times 10^{2}$ & $5,143 \times 10^{3}$ \\
${ }^{131}$ & 364,48 & $1,571 \times 10^{1}$ & 6,926 & $1,495 \times 10^{3}$ \\
${ }^{187} \mathrm{~W}$ & 479,57 & $3,015 \times 10^{2}$ & $2,602 \times 10^{1}$ & - \\
${ }^{124} \mathrm{Sb}$ & 602,73 & $1,606 \times 10^{1}$ & 9,979 & - \\
${ }^{60} \mathrm{Co}$ & 1173,24 & $1,294 \times 10^{1}$ & 0,000 & $2,109 \times 10^{2}$ \\
${ }^{24} \mathrm{Na}$ & 1368 & $9,802 \times 10^{4}$ & $5,173 \times 10^{3}$ & $8,880 \times 10^{4}$ \\
\hline
\end{tabular}

Apabila dibandingkan aktivitas beberapa nuklida dalam air dasar tangki (Tabel 1) dengan nilai hasil pengukuran kualitas air pendingin primer yang diambil sebelum dan setelah melewati resin penukar ion (Tabel 4) serta nilai yang tercantum dalam dokumen LAK RSG-GAS, maka nuklida yang berasal dari air dasar tangki memiliki nilai aktivitas yang lebih tinggi. Ini dimungkinkan karena kontribusi dari produk korosi teraktivasi dan iradiasi batu topaz (pengotor) yang sudah terakumulasi dalam jangka waktu yang cukup lama. Seperti yang sudah disebutkan sebelumnya, iradiasi batu topaz pada posisi incore dilakukan dengan menggunakan wadah terbuka (Gambar 6), sehingga batu topaz dalam kondisi bersinggungan langsung dengan air pendingin reaktor.

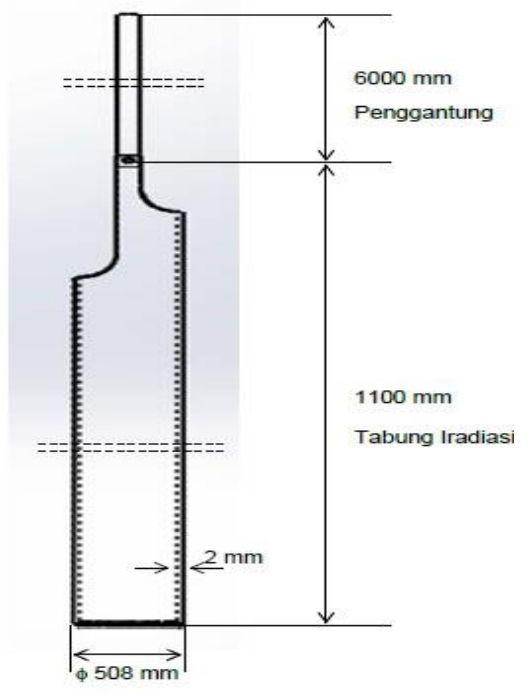

Gambar 6. Wadah alumunium target batu topaz. 
Untuk mempertahankan kualitas air pendingin, reaktor dilengkapi dengan 3 sistem purifikasi KBE-01, KBE02 dan FAK-01, dimana masing-masing sistem terdiri dari filter mekanik yang berupa resin trap dan filter penukar ion (filter ionik) yang berfungsi untuk membersihkan air dari produk aktivasi dan kotoran mekanik, baik itu terlarut maupun tidak terlarut [9]. Di samping itu, pemasangan skimer dalam kolam air pendingin reaktor diharapkan mampu mengurangi pengotor yang mengapung di atas permukaan kolam dan mengurangi jumlah pengotor [10].

Berbagai upaya telah dilakukan agar supaya endapan pengotor dalam air pendingin primer tidak bertambah,diantaranya dengan melakukan pencucian dan pembilasan batu topaz menggunakan air bebas mineral hingga tingkat kekeruhan (turbidity) dari air bekas cucian memiliki nilai yang dipersyaratkan yaitu $\leq 0,6$ NTU (Nephelometric Turbidity Unit) seperti yang tertera dalam prosedur penanganan batu topaz pra iradiasi [11]. Hal ini perlu dilakukan mengingat pada saat ini iradiasi batu topaz sudah dilaksanakan kembali secara rutin di RSG GAS baik pada posisi iradiasi in core maupun out core. Penanganan batu topaz pra iradiasi penting diperhatikan untuk menghilangkan pengotor yang terikut pada batu topaz akibat proses cutting maupun pengangkutan, sehingga tidak menambah jumlah endapan dalam dasar tangki reaktor. Penyedotan air beserta kotoran yang mengendap dengan pompa benam juga perlu dilakukan secara rutin utuk mengurangi jumlah pengotor .

\section{KESIMPULAN}

Jenis radio nuklida terdeteksi dalam air dasar kolam reaktor yang disedot dengan pompa benam memiliki jenis yang sama dengan endapannya. Yaitu ${ }^{51} \mathrm{Cr},{ }^{59} \mathrm{Fe},{ }^{60} \mathrm{Co},{ }^{46} \mathrm{Sc},{ }^{65} \mathrm{Zn},{ }^{125} \mathrm{Sb},{ }^{124} \mathrm{Sb}$. Unsur yang hampir sama ditemukan juga dalam air bekas cucian batu topaz pra iradiasi. Jadi kemungkinan radionuklida terdeteksi adalah hasil aktivasi produk korosi dan efek samping utilisasi reaktor yang sudah menumpuk selama bertahun-tahun. Namun karena sistem purifikasi berfungsi dengan baik maka kualitas air pendingin reaktor selalu terjaga dan berada di bawah nilai yang tercantum dalam dokumen Laporan Analisis Keselamatan. Untuk mencegah bertambahnya endapan produk aktivasi ini dapat dilakukan penyedotan secara berkala serta prosedur penanganan topaz pra iradiasi yang selalu dilakukan sesuai standar operasi yang ditetapkan.

\section{UCAPAN TERIMA KASIH}

Terima kasih untuk semua teman di subbid Keselamatan Operasi Reaktor dan Supervisor reaktor yang telah banyak membantu penelitian ini.

\section{DAFTAR PUSTAKA}

[1] R.L. Sindelar, G.T. Chandler, and J.I. Mickalonis, "Water Quality and Corrosion: Considerations for Nuclear Reactor Systems", Journal of the South Carolina Academy of Science, 9.1, pp. 43-46. 2011.

[2] BATAN RSG-GAS. "Multipurpose Reactor G.A. Siwabessy Safety Analysis Report Rev.10.1". Badan Tenaga Nuklir Nasional (BATAN), Indonesia, Safety Analysis Report Vol. 1, Copy No.1, March 2011.

[3] E. Ratnawati., K. Mustofa, A. Hidayat, "Pengaruh Irradiasi Batu Topaz Terhadap Kualitas Air Pendingin Reaktor GA Siwabessy", Prosiding Seminar Nasional Teknologi dan Aplikasi Reaktor Nuklir, PRSG, pp. 3439, 2012.

[4] Abdul Hafid, "Analysis Of The Inspection Result On The Primary Cooling Pipe Of RSG-GAS Reactor ", Sigma Epsilon, Buletin Ilmiah Teknologi Keselamatan Reaktor Nuklir,19.2, pp. 53-64 2015.

[5] K. Varga, G. Hirschberg, Z. Németh, G. Myburg, J. Schunk, \& P. Tilky, "Accumulation of radioactive corrosion products on steel surfaces of VVER-type nuclear reactors. II. ${ }^{60} \mathrm{Co}$ ". Journal of Nuclear Materials, 298.3, pp. 231-238, 2013.

[6] M. Rafique, N.M. Mirza, S.M. Mirza, K.J. Kearfott, S.A. Abbasi, and S.F. Naeem, Journal of Chemistry Volume 2015, Article ID 809672, 10 pages, Hindawi Publishing Corporation. 
[7] J.I. Malik, N.M. Mirza, and S.M. Mirza, "Simulation of corrosion product activity in extended operating cycles of PWRs under flow rate transient and nonlinearly rising corrosion rates coupled with $\mathrm{pH}$ effects," Nuclear Engineering and Design, 249, pp. 388-399, 2012.

[8] J.I. Malik, N.M. Mirza, and S.M. Mirza, "Time-dependent corrosion product activity in a typical PWR due to changes in coolant chemistry for long-term fuel cycles," Progress in Nuclear Energy, pp. 100-107, 2012.

[9] E.L. Diyah, "Uji Kemampuan Resin Penukar Ion Sistem Purifikasi Air Pendingin Primer Reaktor RSG GAS Menggunakan Air Bekas Pencucian batu" Prosiding Seminar Nasional Teknologi dan Aplikasi Reaktor Nuklir, PRSG, 2014.

[10] E. Ratnawati, E.L. Diyah, " Analisis Pengotor Yang Tertangkap Pada Skimmer Sistem Pendingin Primer Reaktor RSG GAS”, Prosiding Seminar Nasional Pendayagunaan Teknologi Nuklir, 2017.

[11] PRSG, Standar Operasional Prosedur Penanganan Batu Topaz Pra Iradiasi No SOP 005.003./RN 00.01/RSG.2.1 tahun 2016. 